\title{
Jacek Banasiak
}

COBRO - Instytut Badawczy Opakowań, Warszawa

banasiak@cobro.org.pl

\author{
Andrzej Milewski \\ COBRO - Instytut Badawczy Opakowań, Warszawa \\ milewski@cobro.org.pl
}

DOI: 10.35117/A_ENG_16_03_02

\section{Road transport of liquid aluminium}

\begin{abstract}
New casting technologies of crucial aluminum parts for automotive industry are bound with melted aluminum transport and create necessity to define terms and conditions of permission for IBC (Intermediate Bulk Containers) dedicated for this transport. COBRO Packaging Research Institute worked out the IBC testing program and implemented the permission procedure for IBC dedicated for melted aluminum transport according to proper packing instruction included in European Agreement concerning the International Carriage of Dangerous Goods by Road.
\end{abstract}

Keywords: Road transport; IBC; Liquid aluminum

Continuous technological development and the inflow into our country of new investment also pose new challenges for the transport of hazardous materials. In recent years Silesia has produced several large investments related to the automotive industry. Among others in Walbrzych was founded Toyota Motor Manufacturing Poland and in Jelcz-Laskowice Toyota Motor Industries Poland; both producing automotive parts using aluminum components. Economic calculations caused it to handle these two companies, as well as other Group companies Toyota, located outside the borders of our country in the supply of aluminum was formed in Walbrzych plant producing aluminum both in liquid form and in the form of ingots, i.e. semi-finished cast for remelting or for further processing. The company is Poland Smelting Technologies POLST Sp. o.o., which in 2004 he began producing aluminum. With supplied by POLST aluminum alloy foundry customers are manufactured castings, later used in the production of engines, transmissions and other components [4].

Apart from the traditional supply of aluminum alloys in the form of bars, the company supplies aluminum alloys in liquid form directly to the casting machines in the customer's plant. Such a method of delivery of aluminum alloys is considered the most advanced technology. It allows the recipient to avoid metal loss associated with repeated remelting alloys and a significant reduction in energy costs. In addition, this technology contributes indirectly to the reduction of emissions and environmental impact [4].

Transport of liquid aluminum from the company POLST to Toyota Motor Manufacturing Poland does not pose any formal difficulties, and this is due to the fact that the producers' company of liquid aluminum and customers' plant are neighbouring and transport between them is carried out without public roads. In contrast, start engine production at plants in Jelcz-Laskowice has created a need to ensure the conditions for the transport of liquid aluminum are compatible with the requirements of ADR means the European Agreement concerning the international carriage of dangerous goods by road [1] based on the recommendations of the Committee of Experts of the United Nations [2]. 


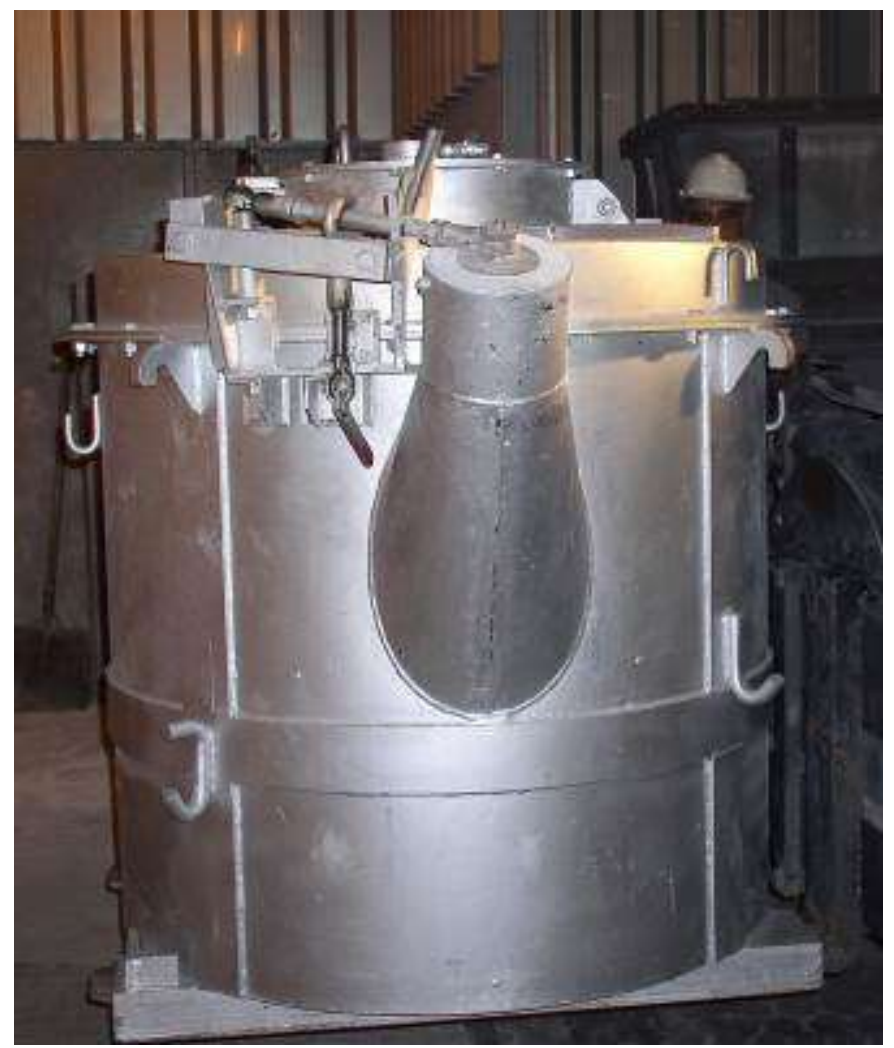

1. IBCs to transport of liquid aluminum

Producer of liquid aluminum wanted to transport the material from its plant in Wałbrzych to the recipient having its plant in Jelcz-Laskowice it is at a distance of about $120 \mathrm{~km}$. This material will be transported in the so-called large containers, intermediate bulk (IBC), made of steel and equipped with several internal refractory and insulating layers. These layers have the main task of maintaining a sufficiently high temperature aluminum (approx. $700{ }^{\circ} \mathrm{C}$ ) by the time of filling the vat through a period of transport to empty the vat at the destination. The containers used by POLST (Fig. 1) have a payload capacity of $0.5 \mathrm{~m} 3$, own weight $1300 \mathrm{~kg}$, and the weight of its contents is $2600 \mathrm{~kg}$. These containers were manufactured by Nippon Crucible Co. Ltd. in Japan.

The use of a particular type of packaging for the transport of dangerous goods must comply with the requirements of packing instructions of this material.

According to ADR, each hazardous material must be classified into one of the thirteen classes. About assigning risk material for one of the classes determined its properties posing specific nature of the threat in transport.

Aluminum in the molten state is classified in Class 9 - Various dangerous substances and articles. The heading of Class 9 covers substances and articles which during transport pose a threat other than that required by the other classes. The materials and articles of Class 9 are divided even further and are marked with classification code M1 to M11, depending on the nature of the threat. Code M9 means liquids with high temperatures and there is aluminum in the molten state having identification number UN 3257th This material is classified in packing group III, i.e. the low-risk materials.

Should be remembered here that each IBC intended for the carriage of hazardous materials must meet certain requirements for its construction. In particular, the IBC shall be resistant to or adequately protected from damage as a result of environmental conditions. They should be made and closed so that in normal conditions of carriage did not exist any 
extraction of the contents. IBCs and their closures shall be made of materials that are tailored for their contents, or be protected internally, so that these materials:

- do not be attacked by the contents so that the use of the IBC would be dangerous;

- do not cause reaction or content distribution, or does not produce harmful or dangerous liaisons.

If the seals are used, they should be made of a material that is not attacked by the products transported in IBCs. All equipment maintenance should be positioned and secured so that the risk of escape of the materials as a result of damage during handling operations and during transport, was limited to a minimum. IBCs, their attachments, as well as service equipment and structural equipment shall be designed and constructed to withstand without loss of contents internal pressure exerted by the contents and are resistant to normal exposure, interacting in handling and carriage. DPPL intended for towering, should be adapted to towering. Lifting or securing features of IBCs shall be of sufficient strength so that they are resistant to exposure under normal conditions of handling and carriage without causing deformation or damage. They should be placed so that there has been no excessive load in any part of the IBC. The IBCs for the carriage of liquids shall be provided for an additional device to seal the drain hole, e.g. by a blank flange or other equivalent device [1].

Dangerous goods intended for transport should be packed in accordance with the appropriate packing instruction. Aluminum in the molten state, which has the identification number UN 3257, should be packed in large bulk containers in accordance with packing instruction IBC99. This manual, in contrast to all the others, is very general in nature and states that may be used only IBC approved by the competent authority. In Poland, the competent authority in the field of technical conditions and testing of packaging of dangerous goods, in accordance with the Act of 19 August 2011 on the transport of dangerous goods [3], the minister responsible for economy, which by regulation empowered COBRO - Research Institute of Packaging in Warsaw for administrative action in matters of technical conditions and testing of packaging of dangerous goods [5].

By joining the activities related to the certification described above IBC, COBRO had to first specify the requirements that must be satisfied that the container can be allowed to transport liquid aluminum. After a thorough analysis, after hearing the opinion of experts COBRO and experts from outside the Institute, taking into account the position of the Technical Committee and taking into account the degree and nature of the risks attached and design features of the IBC provided in the accompanying documentation were set conditions for admission of packaging, in particular the research program required to perform before allowing the IBC to be used for the transport of liquid aluminum.

In developing the research program included the fact that analyzed the IBC was not designed to be lifted from the top and therefore resistance test Top lift was not included in the research program. This is fully in line with the rules for transport of dangerous goods by road. A similar situation occurred when dealing with conditions to check the stacking. According to the presented technical documentation examined the IBC is not structurally designed for stacking and during its use impoundment will not take place. Therefore, the study of the stacking has not been included in the scope of required tests.

Developed research program included:

- resistance test of bottom lifting,

- leak test by gravity method,

- effortless drop test,

- checking the temperature external surface of the container wall. 
Due to the characteristics of the transported material and the specificity of the IBC study had to be made of the original material, which entailed the need for them in the plant producing liquid aluminum, i.e. at POLST.

\section{Resistence test of bottom lifting}

Because planned for use the IBC is adapted to be lifted from the bottom up required to test the resistance in this area. Preparing a container to carry out this study it must be filled so that the total weight lifted IBC was 1.25 times its gross weight. The load should be evenly distributed at the same time. The survey is carried out in such a way that IBC shall be twice raised up and lowered down using a forklift truck. The forks should be made to $3 / 4$ the length of the direction of entry. The study should be repeated in every possible direction of entry.

After the double bearing and leaving the test IBC conducted for each of the two possible sites insert the fork should evaluate the results of the test. The criterion for a positive test result is the lack of any permanent deformation of the IBC unsafe for use. In the case of an investigational IBCs for the transport of aluminum in the molten state, there was no permanent deformations that could arise in the result of attempts to lift from the bottom of.

\section{Leak test by gravity method}

Another study on the prescribed program was a leak test carried out by gravity method. This way of testing has been proposed due to the nature of the product, requiring a special seal. Before the beginning of the study examined the IBC filled to nominal capacity of aluminum in the molten state. Then seal the IBC and using a mechanical lifting reverse tested IBC position upside down (Pic. 2). So reversed IBC shall be kept in this position for 15 minutes.

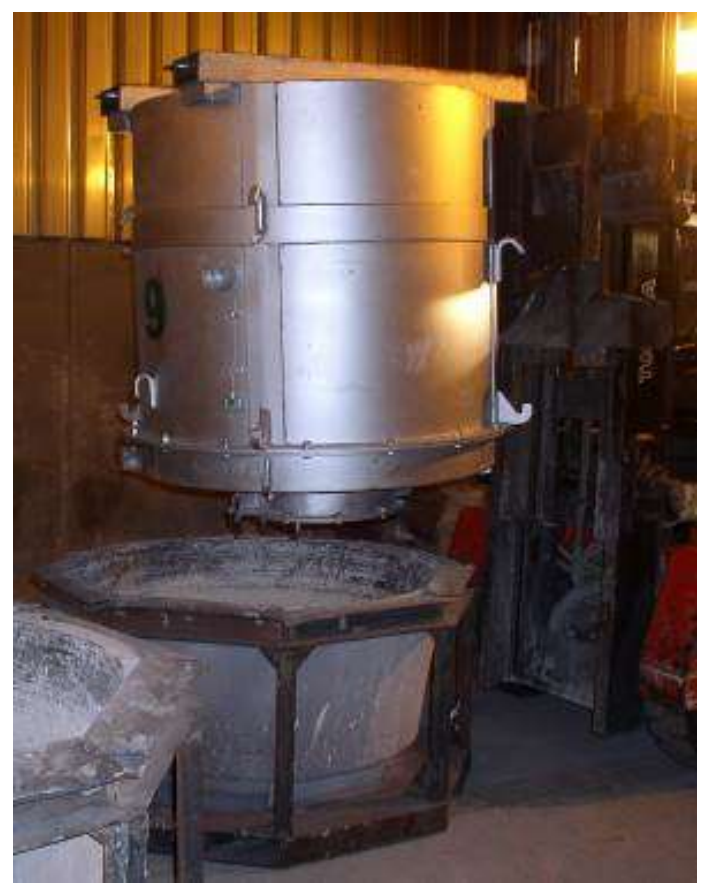

2. Leak test by gravity method

After the required period IBC shall be rotated to its normal position and set on a paved surface. Criterion for passing the test is absence of any leak while maintaining both the IBC inverted upside down, and during its rotation. 
In case of an investigational IBC to the transport of aluminum in the molten state, there was no leakage of aluminum during the test. The state of sealing cap after the test was very good, with no traces of aluminum.

\section{Effortless drop test}

Resistance test carried out on a free-fall must comply with the requirements of ADR. In particular, metal IBC shall be filled to at least $95 \%$ of its capacity. The IBC shall be dropped freely on a rigid, not resilient, smooth, flat and horizontal surface in such a position that it struck with its bottom. Criterion for passing the test of impact resistance by the free fall for the large metal bulk containers is the lack of any loss of contents IBC.

Fall height of IBC depends on the packing group required for the dangerous substance. Because aluminum in the molten state is assigned to packing group III so in carrying out studies of impact resistance by the free fall required drop height is $80 \mathrm{~cm}$. Due to the nature of the hazardous material and taking into account the fact that the study was carried out using the original material for the carrier and the temperature was about $700^{\circ} \mathrm{C}$, in carrying out the study maintained special precautions, and the area of research has been carefully protected.

After the free fall IBC from a height of $80 \mathrm{~cm}$ was made detailed examination of the IBC. There was no loss of liquid aluminum from IBCs.

\section{Checking the temperature external surface of the container wall}

The study was conducted on filled with original material IBC and make measurements of surface temperature and temperature changes in the estimated time of transport. The external surface temperature of the tank should not exceed $70^{\circ} \mathrm{C}$. The study was conducted at IBC filling with molten aluminum to the gross weight of $2600 \mathrm{~kg}$. Measurements of surface temperature was conducted at 9 selected points.

The first measurement was taken at 30 minutes after filling the IBC and the next subsequent measurements were taken every 30 minutes. Temperature measurement was conducted with calibrated non-contact thermometer TESTO 825-T4 with a distance of $2 \mathrm{~cm}$ from the surface of the measurement points. There have been a series of seven measurement temperature for 3.5 hours until filling the IBC with molten aluminum. This period corresponds to the estimated time of liquid aluminum transport from the manufacturer to the customer. As a result of measurement, it was found that in particular measuring points the temperature is stabilized after almost one hour of filling, and thereafter there is a slow decrease in the time.

The result of the carried out certification process taking into account the results of performed tests was to issue the Certification Center COBRO Packaging - Packaging Research Institute certificate granting the right to determination mark UN large container type M8KY manufactured by Nippon Crucible Co. Ltd. in Japan intended for carriage in bulk melt aluminum. Successful completion of the certification process made it possible to fulfill one of the conditions for the safe transport of liquid aluminum. Regular transport of liquid aluminum is now carried out by specially adapted trailers trucks. Developed in COBRO certification procedure IBC to transport liquid aluminum was later used in the evaluation of similar cartridges from other manufacturers, even with a capacity of $2.5 \mathrm{~m} 3$, which gives the gross weight approx. $14 \mathrm{t}$.

\section{Source materials}

[1] ADR - Umowa europejską dotyczącą międzynarodowego przewozu drogowego towarów niebezpiecznych (ADR), sporządzoną w Genewie dnia 30 września 1957 r., wraz ze zmianami obowiązującymi od dnia ich wejścia w życie w stosunku do Rzeczypospolitej Polskiej, ogłoszonymi we właściwy sposób (Dz.U. z 2015 r., poz. 882), 
[2] Recommendations of the Transport of Dangerous Goods, United Nations, New York and Geneva, $19^{\text {th }}$ revised edition, 2015,

[3] Ustawa z dnia 19 sierpnia 2011 r. o przewozie towarów niebezpiecznych (Dz.U. z $2011 \mathrm{r}$. nr 227, poz. 1367),

[4] www.polst.com.pl

[5] Zarządzenie Ministra Gospodarki z dnia 11 października 2013 r. (Dziennik Urzędowy Ministra Gospodarki z 2013 r., poz. 19) 